\title{
ASSOCIATIVITY AND ORGANIZATIONAL CULTURE OF HASS AVOCADO PRODUCTION CHAINS IN THE HUANCAVELICA REGION, PERU 2003-2019
}

\author{
Giomara CAMAC, Evelin GARCIA, Deysi QUISPE, \\ Wiliam RODRÍGUEZ-GIRALDEZ ${ }^{\circledR}$, Wagner VICENTE-RAMOS(D*
}

Faculty of Business Sciences, Continental University, Huancayo, Peru

Received 18 February 2021; accepted 27 May 2021

\begin{abstract}
The objective of the research was to determine the relationship between associativity and the organizational culture of Hass avocado production chains in the Huancavelica Region, Peru in the period 2003-2019. The research is of an applied type, the inductive inferential scientific method was applied. Likewise, the research design used is non-experimental, cross-sectional. A questionnaire was applied to 105 Hass avocado producers from the Huancavelica Region, one of the poorest regions of Peru, in the middle basin of the Mantaro River Valley from the Mariscal Caceres district to the Mantacra town center. In the study, it was found that the associativity environment (ENT) (ASO), based on organizational culture (COR), has a significant influence on the communication dimension $(\mathrm{p}<0.05)$. Regarding support services (SA), has a significant influence on the quality dimension $(p<0.05)$. Also in relationships (REL), they have a significant influence on the communication and adaptability dimensions $(\mathrm{p}<0.05)$. Finally, in government policies $(\mathrm{GP})$, it has a significant relationship with the communication dimension $(\mathrm{p}<0.05)$. Therefore, these dimensions generate a positive impact on organizational culture.
\end{abstract}

Keywords: associativity, organizational culture, environment, support services, relationships, government policies, communication, quality, adaptability.

JEL Classification: O4, Q13.

\section{Introduction}

Rodríguez et al. (2017), point out that associativity in rural areas is established as an inherent condition to the development of small and medium agricultural producers. This allows improving their productive, economic and social conditions through the reduction of their production and transaction costs, improvement of their management processes and links with other actors and transfer of knowledge. Associativity can also be understood as the process of grouping individuals, organizations or companies, voluntarily and by consensus, who work in coordination to achieve their goals. Carbajal et al. (2017), proposes that a key strategy for the development of MSMEs in the globalized world is to promote the associativity of companies, promoting the creation of business clusters and networks, chains, productive and competitive. In addition, associativity is a tactic resulting from a cooperation or alliance of companies based on a common objective, in which each member maintains legal and managerial independence. Despite this desire to promote policies of association and articulation to the market of agricultural producers that have gone hand in hand with the creation of some public programs over the years, such as the Agricultural Research and Extension Project (Incagro), Sierra Exportadora, Agroideas, among other institutions, there is little precision on the type of articulation that seeks to promote, and the lack of research on this subject (Fort \& Vargas, 2015). In general terms, it is stated that members of rural producer organizations seek in various ways to improve their standard of living through collective action. The main functions of these organizations are twofold: a) mediate relations between their members, as well as between them and external economic, institutional and political actors; and $b$ ) provide its associates with a range of services.

According to Rodríguez et al. (2017), in Peru it is very difficult to work under associative schemes due to the individualistic interest that entrepreneurial producers have,

*Corresponding author. E-mail: wvicente@continental.edu.pe

Copyright $\odot 2021$ The Author(s). Published by Vilnius Gediminas Technical University

This is an Open Access article distributed under the terms of the Creative Commons Attribution License (http://creativecommons.org/licenses/by/4.0/), which permits unrestricted use, distribution, and reproduction in any medium, provided the original author and source are credited. 
so various forms of associativity range from the productive aspect to the associativity of a brand. Interaction is one of the most difficult elements. For this, the unions play a very important role in making them known, training and deciding to work together. The lack of associativity in Peruvian companies is due to the scarce trust that exists and the high transaction costs, trust is one of the pillars for articulation, association and motivates joint actions, therefore it is one of the pillars that determine the consolidation of the associative schemes of the business organization.

In Peru there are cases of successful associativity in the coffee sector, which is currently the best organized in the country, at the national level $32 \%$ of coffee producing families (out of a total of 160,000) are organized in cooperatives, generating at year sales abroad of the order of US $\$ 1,580$ million, equivalent to $33 \%$ of agricultural exports. Another outstanding case is the organization of banana growers from the Chira Valley in Piura, where 95\% are organized and it is the main exporter of organic bananas nationwide.

Through a study carried out in the middle basin of the Mantaro River Valley, one of the Hass avocado producers affirms that the members of the said association do not have very clear goals as an association and the producers are not very interested in organizing themselves, so it is It is clear that the meetings that are held are scarce, it also indicates that the farmers of that area are reluctant to change their crops and customs (Lerner, 2013). In recent years what is wanted is that they work as a team, stop working as a team. Individually and the different ways of thinking of the producers, and must establish common visions, missions and objectives to improve results.

It should be noted during the trip to carry out the surveys of Mr. Epifanio Chanchas, representative of the agricultural producers association Chanchas, comments that he is one of the oldest in the production and sale of Hass avocado and some fruit trees in the town of Mantacra, began at the beginning of 2003 with some plantations, for which he requested help from some public entities for advice, but they were denied because they thought that the climate was not favorable for production and other limiting factors. Today it has an association of 30 members, it also has the help of public institutions for training, advice and help to cover costs.

This study aims to determine the relationship between associative work and the organizational culture of productive chains of agricultural producers of Hass avocado in the Huancavelica region, Peru, in the period 2003-2019. What is sought through the association of producers is to improve the family economy and quality of life of the associates, for this reason it insists on promoting associativity for sources of financing, technical training, marketing networks so that associations are sustained alone, generating work and income for their families.

\section{Literature review}

\subsection{Asociativity}

Associativity is a strategy aimed at promoting the achievement of a competitive advantage by a company through cooperation or the establishment of agreements with other companies, to carry out a series of activities within the value chain, giving rise to to a greater presence of the company in one or more markets (Rodríguez-Giráldez \& Vicente-Ramos, 2020). Furthermore, associativity is understood as an instrument that, without undermining the independence of the associates, facilitates their competitiveness. This makes it possible to voluntarily decide to trust each other and share knowledge, experiences and strengths, so that their link is the responsibility of a single body that is capable of promoting them and enhancing their comparative advantages (Alba et al., 2018). Therefore, associativity is based on the following aspects: it is a collective strategy, it allows solving common problems while maintaining the managerial independence of the associates, it is voluntary, it is inclusive since it does not limit access, it allows the adoption of various legal forms organizational and focuses on models for small businesses or small business owners.

\subsubsection{Environment}

Carbajal et al. (2017), points out that the environment in a production chain evaluates the climatic, cultural and economic processes that affect the development of the production chain, and according to the context that is being managed, the production process is considered from the inputs, processing, final product until the national and international commercialization of the same. On the other hand, the company is also capable of influencing these factors positively through a communication strategy. The most common factors that can intervene in the specific business environment are human resources, customers, suppliers and competition.

\subsubsection{Supporting services}

Alandia Soto (2007), defines economic units dedicated mainly to providing business support services (such as business administration services, hiring and placement of personnel, document preparation, reception of telephone calls, collection, travel organization, surveillance and security, building cleaning, product packaging and labeling) to facilitate daily operations.

\subsubsection{Relationships}

It is defined as the reciprocal interaction between two or more people within the work environment that generates trust and therefore enters your life and at the same time lets that other people enter yours. Likewise, relationships are the purchase-sale, social and organizational connections that exist in the elements that form and participate in the production chains (Carbajal et al., 2017). 


\subsubsection{Government policies}

Public policies are a common factor in the politics and decisions of the government and the opposition. Thus, government policy can be analyzed as seeking to establish public policies on certain issues, or to influence them. In turn, a fundamental part of what the government does refers to the design, management and evaluation of public policies. Likewise, Gómez Díaz de León (2015), mentions that the government's policies of excellence have characteristics that favor a better political discussion, which are: estimation of costs and financing alternatives, factors for an evaluation of social benefit-cost and clarity of objectives.

\subsection{Organizational culture}

Organizational culture is the idea that a common perspective, shared beliefs, and common values among the organization's participants will enhance coordination and promote a sense of ownership on the part of its members. It is also the idea that norms and beliefs enhance the organization's ability to receive, interpret and translate signals from the environment in the internal organization (Baker, 2002). In addition, Schein (2010), refers to the set of values, needs, expectations, beliefs, policies and norms accepted and practiced by them. Organizational Culture is framed by communication, quality and adaptability.

\subsubsection{Communication}

Bambaeeroo and Shokrpour (2017), mentions that communication means social development and a source of cultural and spiritual development, and the lack of communication leads to a relatively static state in human life, which prevents any type of social development, one of the characteristics of professionals is their ability to establish an effective and meaningful relationship. Communication is that which arises in the structure of an organization and flows through its channels. Through this flow tasks, objectives, discipline, orders, questions, organizational policies, motivation Ocon et al. (2017).

\subsubsection{Quality}

Quality is a matter of survival; achieving it becomes a longterm strategy. It is about quality of life, work, people, the institution, its objectives, its processes and, in general, all the elements of the company. Quality is profitability, productivity, participation in the market; It is a series of elements that combine in a coordinated way and signify business success. Likewise, Ibáñez et al. (2015) mentions that quality should be understood as a responsibility of all those involved in the process, but especially of management. To really achieve quality, it is necessary to listen to the customer, take into account their complaints, claims, returns, suggestions, etc. The benefits of quality translate into greater productivity, conquering and ensuring customer loyalty, guaranteeing a market space for the company or institution and allowing it to remain faithful to its objectives.

\subsubsection{Adaptability}

They are events that workers easily adapt and face the nature of these situations, efficiency and fluency can change their orientation or focus when necessary, and to what extent they take reasonable measures, despite the uncertainty and ambiguity inherent to the situation (Pulakos et al., 2000). Also adaptability is the ability of a system to change to adapt to various circumstances, it is an important attribute of contemporary products. Uncertainties in future market needs, customer requirements, technology capabilities, and material costs (just to name a few of the critical uncertainties faced by product developers and producers), as well as wishes for variety and customization, make adaptability valuable (Engel et al., 2017).

\section{Research method and hypotheses}

The design of the research model (Figure 1) was elaborated from the literary review, where the associativity construct has the following dimensions and items:

Environment (ENT), considers the climate, cultural and economic. The study considered the climate of the work area favorable for the production of avocado or avocado (AECL1), in the association there is a good work environment (AECU1), the association has large hectares for cultivation (AEEN1), the accesses of the roads are favorable for commercialization (AEEN2), there is a technified irrigation system (AEEN3).

Support services (SA), includes technical, business, financial and research services, and the study considered: it has technical support from specialists in production, harvest and post harvest (ASAT1), it has the support of the National Service of Agrarian Health SENASA and another public organization to have production certifications (ASAT2), they have training, teamwork, associativity and leadership (ASAE1), they have the support of avocado exporting companies (ASAE2), institutions Financial institutions offer credits for agriculture (ASAF1), there is training support, technical assistance and market promotion by public institutions (ASAI1), a technological guide for avocado cultivation is followed (ASAI2).

Relationships (REL) contemplates buying and selling, social and organizational relations. The study considered: all inputs for cultivation are purchased together (ARCV1), they are sold together (ARCV2), meetings are generated to carry out all production activities (ARS1), the members of the association have an action plan for situations that may arise (ARS2), the Agroexport companies (ARO1) are trusted.

Government Policies (PG), includes support institutions and support programs, and the study considered: there is support for training and technical assistance from MINAGRI (APGIA1), there is support from AGRORURAL for marketing (APGIA2), training on the management of avocado pests and diseases is received by the Regional Agrarian Directorate DRA - Huancavelica (APGPA1), support is received for the formation of associativity by AGROIDEAS (APGPA2). 
For the construct organizational culture, the following dimensions and items:

Communication (COM), contemplates teamwork and leadership, and the study considered: communication between the members of the association is good (COCTE1), the members of the association contribute so that there is adequate communication (COCTE2), Members of the association trust and help each other (COCTE3), all participate in decision-making (COCL1), the leadership that is exercised allows the development of the association (COCL2).

Quality (CAL), contemplates technology and total quality, and it was considered: The physical working conditions are adequate to develop skills (COCaT1), the work done satisfies (COCaTV1), the work done motivates (COCaTV2), the work performed improves the quality of life of the members (COCaTV3).

Adaptability (ADT), contemplates orientation to change and conflict resolution, and it was considered: everyone collaborates to generate changes in the association (COAOA1), the work in the association is carried out in a coordinated manner and with measurement of results (COAOA2), all collaborate in facilitating recourse and eliminating obstacles in the company (COARC1), when there are conflicts, the causes to resolve them are identified (COARC2).

From which the following conceptual model and hypothesis are established.

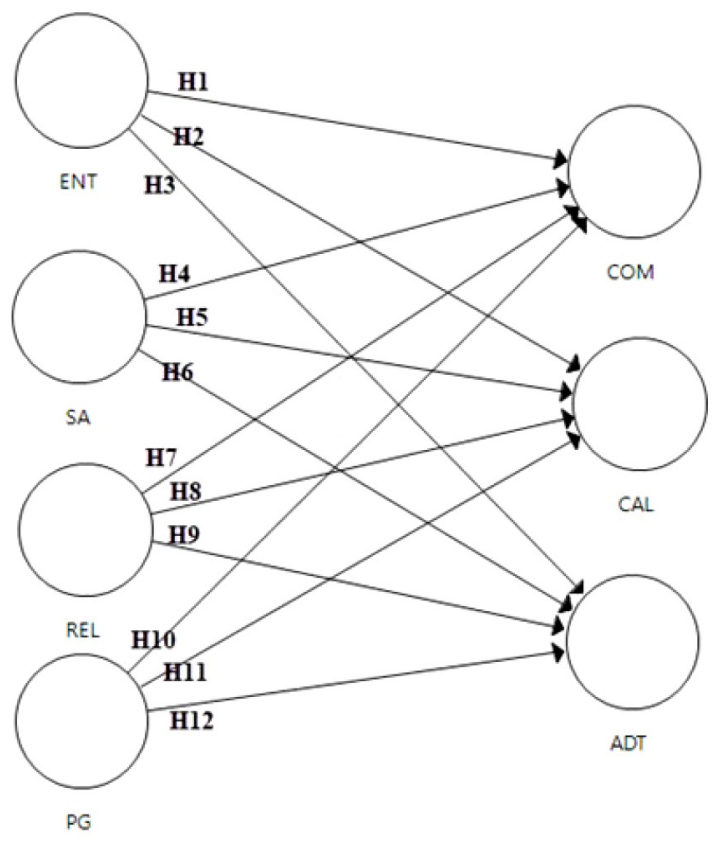

Figure 1. Conceptual model and hypotheses

H1: The associativity environment (ENT) generates a positive impact on the communication of the organizational culture (COM).

$\mathrm{H} 2$ : The associativity environment (ENT) generates a positive impact on the quality of the organizational culture (CAL).
H3: The associativity environment (ENT) generates a positive impact on the adaptability of the organizational culture (ADT).

H4: The support services of the associativity (SA) generate a positive impact on the communication of the organizational culture (COM).

H5: The support services of the association (SA) generate a positive impact on the quality of the organizational culture (CAL).

H6: Associative support services (SA) generate a positive impact on the adaptability of the organizational culture (ADT).

H7: Associative relations (REL) generate a positive impact on the communication of the organizational culture (COM).

H8: Associative relationships (REL) generate a positive impact on the quality of the organizational culture (CAL).

H9: Associative relationships (REL) generate a positive impact on the adaptability of the organizational culture (ADT).

H10: Government policies based on associativity (PG) generate a positive impact on the communication of the organizational culture (COM).

H11: Government policies based on associativity (PG) generate a positive impact on the quality of the organizational culture (CAL).

H12: Government policies based on associativity (PG) generate a positive impact on the adaptability of the organizational culture (ADT).

\section{Method}

In applied research and explanatory level, the deductive inferential scientific method was applied, since it is intended to measure the causal link that exists between the study variables. Likewise, the research design used is the non-experimental cross-sectional design.

\subsection{Population and sample}

The study population is made up of agricultural producers of Hass avocado in the Huancavelica Region, made up of women $(29.5 \%)$ and men $(70.5 \%)$, with an age range between 30 to 50 years or more. A sample of 105 agricultural producers of Hass avocado was obtained, which are found in the Huancavelica region in the middle basin of the Mantaro river.

\subsection{Data collection instrument}

A directed questionnaire was developed, for the construction of the instrument the book "Organizational Behavior" by Robbins (2004) was consulted, as well as the manuscript by Sánchez et al. (2018). From this first stage of information gathering, the principles and characteristics of the companies that follow the associativity and organizational culture model were obtained. For the validation of the instrument, the Delphi methodology was followed, 
so the background validation was carried out by 7 experts in Administration, International Business and Research (from the cities of Lima, Arequipa, Huancayo and Huancavelica). Likewise, the form was validated by applying the survey to 35 agricultural producers from Huancavelica, who participated simultaneously in the pilot. After the first correction of the observations - made by the experts and the businessmen - the instrument underwent a second validation, in charge of 3 expert researchers from the city of Huancayo. In these stages (for validation of substance and form), the evaluation of the questions was considered on a scale of ten points (zero not understandable and ten completely understandable), so that at the end of this process each question reached a score value mean greater than or equal to seven points; These stages verified the understanding of the questions, identified gaps in the items, eliminated questions, and fine-tuned the data collection mechanism.

\section{Results}

\subsection{Assessment of the measurement model}

Table 1 shows the measurement analysis of the model, based on the reliability and validity of the measurement scales. Regarding reliability, the internal consistency of the scales is evidenced through the Cronbach Alpha value (between 0.755 to 0.941 ) and the composite reliability (between 0.860 to 0.916 ). Concerning convergent validity, all factor loadings are above 0.760 . Likewise, all the scales have percentages of average variance extracted (AVE) greater than $50 \%$. The discriminant validity of the construct was tested by the Fornell Larcker criteria, which verifies the independence of each of the scales, considering that the square root of the AVE is greater than the correlations with the rest of the scales. In all cases an R2 greater than 0.500 was obtained, which is very significant, showing that the model significantly explains the variance of the conceptual constructs of the dependent variable.

\subsection{Assessment of the structural model}

After verifying the validity and reliability of the measurement model, the relationships of the constructs were tested. The hypotheses were tested by examining the correlation coefficients and their levels of significance. Bootstrapping was performed with 6000 subsamples to verify the statistical significance of each of the road coefficients. Figure 2 shows the estimated trajectory of the PLS analysis.

Considering that 5 specific relationships have $\mathrm{p}<0.05$, the proposed hypotheses $\mathrm{H} 1, \mathrm{H} 5, \mathrm{H} 7, \mathrm{H} 9$ and $\mathrm{H} 10$ are accepted as shown in Table 2.

Table 1. Results of the model measurement analysis

\begin{tabular}{|c|c|c|c|c|c|}
\hline Variables & Cronbach alpha & $\begin{array}{c}\text { Composite } \\
\text { reliability }\end{array}$ & Factor loads (range) & $\begin{array}{c}\text { Average variance } \\
\text { extracted (AVE) }\end{array}$ & $\begin{array}{c}\text { Discriminant } \\
\text { Validity }\end{array}$ \\
\hline ENT & 0.755 & 0.860 & $0.804-0.827$ & 0.671 & 0.819 \\
\hline SA & 0.931 & 0.951 & $0.888-0.931$ & 0.829 & 0.911 \\
\hline REL & 0.930 & 0.951 & $0.892-0.943$ & 0.828 & 0.910 \\
\hline PG & 0.908 & 0.935 & $0.842-0.912$ & 0.784 & 0.885 \\
\hline COM & 0.941 & 0.955 & $0.835-0.952$ & 0.810 & 0.900 \\
\hline CAL & 0.886 & 0.921 & $0.764-0.907$ & 0.744 & 0.863 \\
\hline ADT & 0.918 & 0.942 & $0.848-0.940$ & 0.803 & 0.896 \\
\hline
\end{tabular}

Table 2. Results of the model structure analysis

\begin{tabular}{|c|c|c|c|c|c|}
\hline Hypotheses & Mean sample & Standard deviation & Beta & p value & Decision \\
\hline ENT -> COM & 0.244 & 0.097 & 2.446 & 0.014 & Accept H1 \\
\hline ENT - CAL & 0.266 & 0.181 & 1.479 & 0.139 & Denies H2 \\
\hline ENT -> ADT & 0.192 & 0.113 & 1.627 & 0.104 & Denies H3 \\
\hline SA - COM & 0.070 & 0.097 & 0.812 & 0.417 & Denies H4 \\
\hline SA -> CAL & 0.630 & 0.129 & 4.878 & 0.000 & Accept H5 \\
\hline SA - ADT & 0.158 & 0.137 & 1.195 & 0.232 & Denies H6 \\
\hline REL -> COM & 0.390 & 0.173 & 2.244 & 0.025 & Accept H7 \\
\hline REL -> CAL & 0.036 & 0.273 & 0.075 & 0.940 & Denies H8 \\
\hline REL -> ADT & 0.697 & 0.114 & 6.031 & 0.000 & Accept H9 \\
\hline PG -> COM & 0.230 & 0.139 & 1.706 & 0.048 & Accept H10 \\
\hline PG -> CAL & -0.156 & 0.174 & 0.749 & 0.454 & Denies H11 \\
\hline PG -> ADT & -0.134 & 0.119 & 1.021 & 0.307 & Denies H12 \\
\hline
\end{tabular}




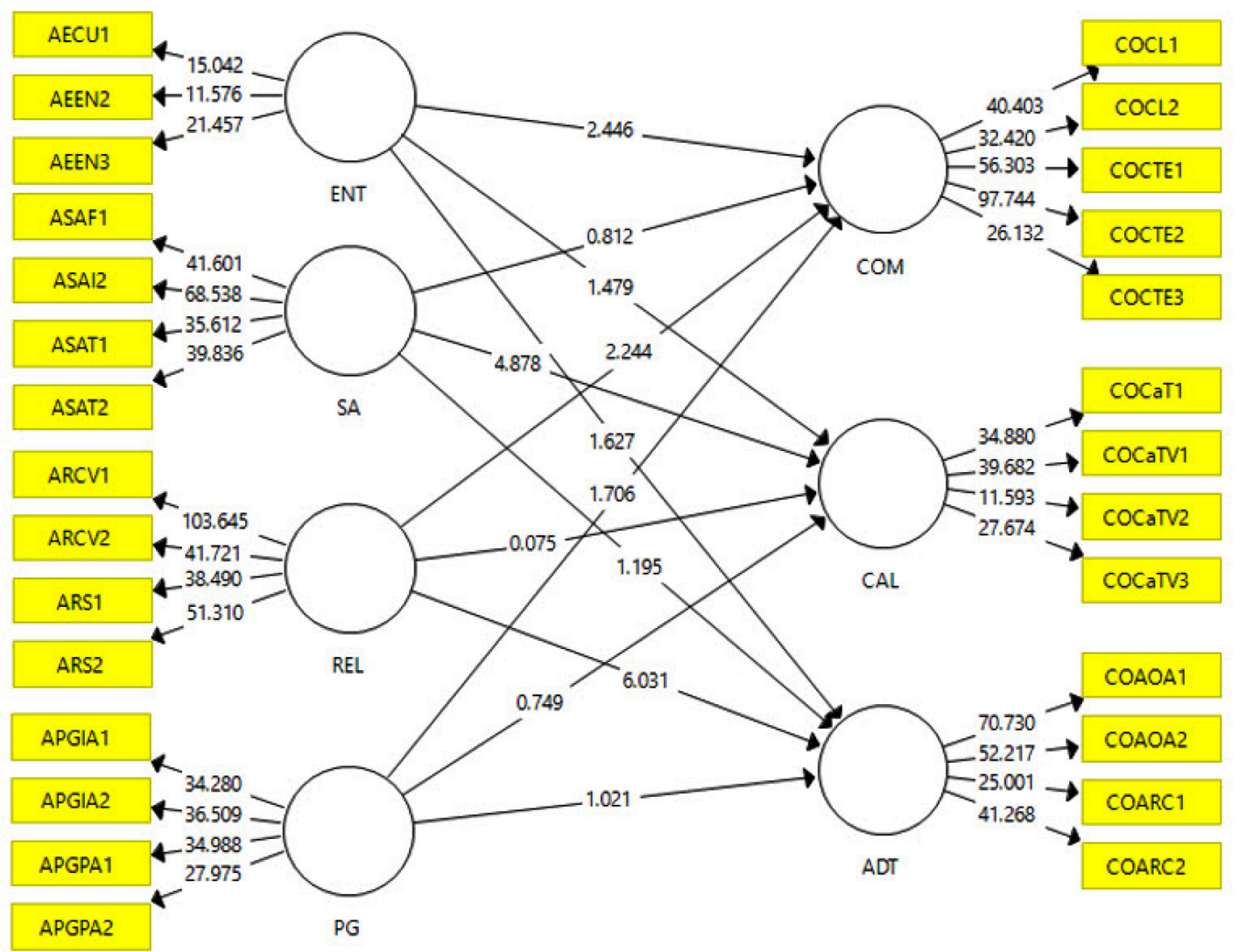

Figure 2. Modeling of associativity and organizational culture

\section{Discussion and conclusions}

\section{Regarding the impact of the associativity environment on the organizational culture}

In the study, it was found that the associativity environment, based on organizational culture, has a significant influence on the communication dimension $(p<0.05)$, as well as a negative implication on the quality $(p>0.05)$ and adaptability ( $p>0.05)$. Gomes de Castro (2003), establishes that the environment must be included in a production chain because climatic, cultural and economic processes affect the development of the production chain, and according to the context that is being managed, the process is considered productive from inputs, processing, final product to national and international marketing thereof. In this sense, the environment in the production chain is very important; It can be said that this aspect explains its low reliability, because in reality the buyer's markets are out of the context as well as most of the suppliers, which are usually centralized by the government.

\section{Regarding the impact of the support services of the association, in the organizational culture}

The results of the research show that associativity support services, based on organizational culture, have a significant influence on the quality dimensions ( $\mathrm{p}<0.05)$, a negative relationship with the communication dimensions $(\mathrm{p}>0.05)$ and adaptability $(\mathrm{p}>0.05)$. According to De Sousa (2016), in a study titled "Support for the development and strengthening of the ramón seed (Brosimum alicastrum Swartz) value chain and its contributions to protect the habitat of the jaguar (Panthera onca L.) in the Reserva de la Biosfera Maya, Petén-Guatemala" made a representation in a table, the main business development services (SDE) offered in the chain and were classified into operational services, technical and business services, financial services, organizational services and business services. Commercialization. After identifying these main BDS, a scoring table was made where 1 is the lowest rating and 3 is the highest, seeking to identify the perception of the actors on the quality of the BDS. According to the interviewed actors, all BDS are very important in which only three stand out, technical and business services and organizational services, which have contributed significantly since they have allowed the creation of capacities and the strengthening of the human capital of women from community producer groups. Also Szmulewicz et al. (2012), specialist on the issue of the consolidation of agrotourism as a new productive activity that contributes to rural development in southern Chile, points out that to strengthen the groups of entrepreneurs responsible for designing, offering and marketing, they must achieve the necessary support so that peasants and small producers can access the necessary training, technical assistance and financial resources to materialize their new businesses. Each group 
must develop new techniques for the participation of partners in decision-making.

\section{About the impact of associative relationships, in the organizational culture}

Associativity relationships, based on organizational culture, have a significant influence on the communication dimensions $(\mathrm{p}<0.05)$ and adaptability $(\mathrm{p}<0.05)$ and a negative relationship link with the quality dimension $(\mathrm{p}>$ 0.05). Villano Ludeña and Villegas Huamani (2018) affirm that relations between producers are successful in an associative work model by $53.3 \%$ because they are willing to share work tools such as their knowledge, especially in the process of growing native potatoes due to to good communication between them. Likewise, Fernández et al. (2020) points out that the relationships between the actors in the honey chain should focus on establishing common goals and analyzing opportunities. The relationships between the actors should economically benefit all the participants according to the risks they assume or the investments they make. At the same time, the relationships between the actors in the chain require the creation and strengthening of bonds of trust and effective information exchange.

Pérez et al. (2016), states that interpersonal relationships are essential to obtain new knowledge and new ideas to innovate. An example of these routines could be the establishment of monthly meetings between the top leadership and the grassroots cooperatives, proposing a topic for debate and reflection that will continue throughout the year. Improvement plans, new procedures and techniques, new organizational routines will emerge from these meetings.

Szmulewicz et al. (2012), affirms that for the successful development of an associative organization, the active participation of its members in the activities and meetings that take place is relevant and suggests the periodic holding of general assemblies where the board of directors gives an account of the management carried out and of their work plans, which will allow greater transparency and the distrust or envy that members may feel towards their representatives will be reduced.

\section{Regarding the impact of government policies based on associativity, on the organizational culture}

The associativity government policies, based on organizational culture, show a negative relationship with the communication dimension ( $p>0.05)$, as well as a negative implication in the quality $(\mathrm{p}>0.05)$ and adaptability $(\mathrm{p}>$ 0.05) dimensions. Fernández et al. (2020) points out that the success of the productive chains depends on the efforts of technological updating, marketing, as well as the support of the government. In Mexico, small production is supported, the government agency helps in the development of protocols that allow adaptation to international market regulations. On the other hand, to comply with said regulations, the government provides technical advice, infrastructure support and supply of inputs. The government, through the agricultural agencies, can play a key role in dialogue and agreements between the chain's actors. In this way it could encourage rural development for the benefit of small producers. Finally, public policy should also focus on strengthening producer organizations and collective action in the chain. According to Pietrobelli and Rabelloti (2005) in their study. Improving competitiveness in clusters and production chains in Latin America, they point out that policies have to be incorporated in different business, cultural and institutional settings. Finally, policies have to evolve over time to consider the evolution of business concentrations and production chains. Therefore, the participation of all possible institutions is required.

Medina Robayo (2005) in a study carried out concludes that the Colombian government has made several advances in competitiveness policies in the fruit sector in Colombia, in which some projects such as innovation, productive processes, infrastructure and training were found, through Public institutions of the Colombian government, although it is necessary to create more sources of financing in the fruit sector, even if the government has helped through the National Fund for Agricultural Risks FINAGRO and the Quotas de Fomento Hurtofrutícula this support from these institutions has helped the farmers to make their products more competitive in the international market.

One of the limitations that was had was access to other communities where a greater amount of Hass avocado was produced, as well as the community of Quichuas and Santa Rosa de Mallma, because the population did not allow access to people who were not from the town for fear of contagion from COVID 19. Likewise, it could not be covered in its entirety because the Huancavelica region re-entered quarantine because it was declared one of the regions with a high risk of contagion.

\section{Acknowledgements}

The authors are grateful for the support of the representatives and members of the Hass avocado producing associations of the Mariscal Caceres District, the town of Carpas and the town center of Mantacra, located in the middle basin of the Mantaro-Huancavelica river, for giving us their Time to carry out the questionnaires on Associativity and Organizational Culture of Hass avocado production chains in the Huancavelica Region, Peru 2003-2019.

\section{Author contributions}

Giomara Camac, was responsible for data collection.

Evelin Garcia, conceived the study and was responsible for the design and development of the findings.

Deysi Quispe, was in charge of analyzing the results and interpreting the data.

Wiliam Rodríguez- Giráldez, was in charge of the discussion of results and conclusions.

Wagner Vicente-Ramos, wrote the first draft of the article. 


\section{Disclosure statement}

The authors do not have any conflict of interest

\section{References}

Alandia Soto, M. D. (2007). Necesidad de una ley específica que regule las operaciones de microcreditos en Bolivia [Doctoral dissertation, La Paz-Bolivia]. https://repositorio. umsa.bo/xmlui/bitstream/handle/123456789/18877/T-2185. pdf? sequence $=1$ \&isAllowed $=y$

Alba, O. Y., Arévalo, G. H., \& Rojas, L. B. (2018). Associativity: an alternative to strengthen competitiveness. Revista Sinapsis, 10(1), 45-53. https://app.eam.edu.co/ojs/index.php/ sinapis/article/viewFile/174/312

Arce Baltazar, G. J., \& Malvas Rojas, Y. M. (2014). El clima organizacional y las relaciones interpersonales en la IE Manuel González Prada de Huari-2013. http://repositorio.ucss. edu.pe/bitstream/handle/UCSS/134/Arce_Malvas_tesis_ maestr\%C3\%ADa_2014.pdf? sequence=18isAllowed $=y$

Baker, K. A. (2002). Organizational culture. US Department of Energy, Office of Science.

http://citeseerx.ist.psu.edu/viewdoc/download?doi=10.1.1.43 9.8759\&rep $=$ rep $1 \&$ type $=$ pdf

Bambaeeroo, F., \& Shokrpour, N. (2017). The impact of the teachers' non-verbal communication on success in teaching. Journal of Advances in Medical Education \& Professionalism, 5(2), 51-59.

https://www.ncbi.nlm.nih.gov/pmc/articles/PMC5346168/

Carbajal, L. M. B., Tovar, L. A. R., \& Zimmerman, \& H. F. L. (2017). Model of associativity in the production chain in Agroindustrial SMEs. Contaduría y administración, 62(4), 1118-1135. https://doi.org/10.1016/j.cya.2017.06.010

CoMexPerú. (2020). Agro exportaciones se estancan en la primera mitad del 2020. https://www.comexperu.org.pe/articulo/ agroexportaciones-se-estancan-en-la-primera-mitad-de-2020

De Sousa, S. C. D. (2016). Apoyo al desarrollo y fortalecimiento de la cadena de valor de la semilla de ramón (Brosimum alicastrum Swartz) y sus aportes para proteger el hábitat del jaguar (Panthera onca L.) en la Reserva de la Biosfera Maya, PeténGuatemala (No. Thesis S725ap). CATIE, Turrialba (Costa Rica). http://repositorio.bibliotecaorton.catie.ac.cr/bitstream/ handle/11554/8598/Apoyo_al_desarrollo_y_fortalecimiento. pdf? sequence $=1$ \&isAllowed $=y$

Díaz, F. R. V., Peceros, R. I. R., \& Chipana, E. G. (2020). Situation of the associativity In Papa Producers of The Andahuaylas Province, Apurímac Region, Peru. Journal of Research and Opinion, 7(3), 2676-2683. https://doi.org/10.15520/jro.v7i3.58

Engel, A., Browning, T. R., \& Reich, Y. (2017). Designing products for adaptability: insights from four industrial cases. Decision Sciences, 48(5), 875-917.

https://doi.org/10.1111/deci.12254

Fernández, L. A. P., Durán, H. P. R., Anguebes-Franceschi, F., \& Fernández, J. M. P. (2020). Eficiencia económica y organización de la cadena productiva de miel en Campeche, México. Agricultura Sociedad y Desarrollo, 17(1), 71-90. https://doi.org/10.22231/asyd.v17i1.1323

Fort, R., \& Vargas, R. (2015). Estrategias de articulación de los productores agrarios en la costa peruana: asociatividad, vinculación con empresas o ambas? https://www.grade.org.pe/ publicaciones/estrategias-de-articulacion-de-los-productores-agrarios-en-la-costa-peruana-asociatividad-vinculacion-con-empresas-o-ambas/
Gomes de Castro, A. (2003). Foresight study on the productive chain on the fishery industry in the region den South American Pacific Coast [consultado 12 Ago 2008].

http://cpps.dyndns.info/cpps-docs-web/planaccion/biblioteca/pordinario/033.foresight_study_fish_report.pdf

Gómez Díaz de León, C. (2015). Sistema politico y formas de gobierno. http://eprints.uanl.mx/8760/1/Documento1.pdf

Ibáñez, D. P. S., Cabrera, B. C. C., Martínez, J. A. A., Martínez, A. R., \& Maldonado, J. R. (2015). Asociatividad para la competitividad en la agroindustria de oaxaca, México. Revista mexicana de agronegocios, 36, 1167-1177. https://www.redalyc.org/pdf/141/14132408003.pdf

INEI. (2017). Directorio Nacionlal de Centros Poblados - Censos Nacionales 2017:XII de Población, VII de Vivienda y III de Comunidades Indígenas. https://www.inei.gob.pe/media/MenuRecursivo/publicaciones_digitales/Est/Lib1539/libro.pdf

Lerner, D. (2013). Las paltas del Mantaro. Revista Quehacer, 189, 106-113. Gale OneFile: Informe Académico.

https://www.desco.org.pe/recursos/sites/indice/841/3752.pdf

López Portilla, D., Espinoza Montesinos, E., Hinojosa Benavides, R. A., \& Portales Ceballos, C. (2014). Nuevo sistema de agricultura orgánica en la UDEA Angaraes-Huancavelica. http://repositorio.udea.edu.pe/handle/123456789/24

Medina Robayo, L. C. (2005). El papel de las políticas de competitividad en el sector frutícola colombiano-desempeño y retos [Bachelor's thesis, Uniandes].

https://repositorio.uniandes.edu.co/bitstream/handle/1992/ 22331/u263304.pdf? sequence $=1$

MINAGRI. (2015). Unidad de imagen institucional MINAG. https://www.midagri.gob.pe/portal/notas-de-prensa/notasde-prensa-2012/7680-minag-cuenta-con-consejo-de-imagen-corporativa

Ocon Cedillo, E., Ramírez Barón, M. C., \& Flores Martínez, P. (2017). Nivel De Relación Del Compromiso Organizacional, Comunicación Organizacional Y La Satisfacción Del Trabajo: Evidencia Desde México [Relationship between of the Organizational Commitment, the Organizational Communication and the Work Satisfaction: Evidence from México]. Revista Internacional Administración \& Finanzas, 10(4), 81-89. http://www.theibfr2.com/RePEc/ibf/riafin/riaf-v10n4-2017/ RIAF-V10N4-2017-7.pdf

Osorio Vargas, C., \& Ramírez González, G. (2017). La comunicación y difusión de las políticas públicas de gobierno. Aspectos constitucionales, legales y presupuestarios. Revista de Derecho Público, (85), 141-184. https://doi.org/10.5354/0719-5249.2016.44963

Pérez, A. M. G., Cervantes, C. R., \& Martínez, M. G. (2016). De la cooperativa agroalimentaria a la "learning netchain". Hacia un planteamiento teórico interorganizativo e interpersonal. Revesco. Revista de Estudios Cooperativos, 121, 114-144. https://doi.org/10.5209/rev_REVE.2016.v121.51304

Pietrobelli, C., \& Rabellotti, R. (2005). Mejora de la competitividad en clusters y cadenas productivas en América Latina (pp. 10-78). Banco Interamericano de Desarrollo.

Plata, C. A. (2017). Administration and the administrative process. Universidad de Bogotá Jorge Tadeo Lozano. https://ccie.com.mx/wp-content/uploads/2020/04/ProcesoAdministrativo.pdf

Pulakos, E. D., Arad, S., Donovan, M. A., \& Plamondon, K. E. (2000). Adaptability in the workplace: Development of a taxonomy of adaptive performance. Journal of Applied Psychology, 85(4), 612-624.

https://doi.org/10.1037/0021-9010.85.4.612

Rodríguez, A. B., Reyes, V. C., García, A. G. R., \& García, A. E. (2017). Identification of organizational innovation components 
to consolidate rural associative enterprises. Revista de Geografía Agrícola, (59), 127-144.

https://doi.org/10.5154/r.rga.2017.59.006

Rodríguez-Giráldez, W., \& Vicente-Ramos, W. (2020). Cultural aspects that influence the associative work of agricultural production chains in the Mantaro Valley of Peru. Management Science Letters, 10(11), 2425-2430.

https://doi.org/10.5267/j.msl.2020.4.008

Robbins, S. P. (2004). Comportamiento organizacional. Pearson educación.

Romero, I., \& Tejada, P. (2011). A multi-level approach to the study of production chains in the tourism sector. Tourism Management, 32(2), 297-306. https://doi.org/10.1016/j.tourman.2010.02.006

Sánchez, A., Hernández, T. J., Martínez, E., Villegas, E., \& García, C. (2018). Cultura organizacional en microempresas activadoras del desarrollo local. Margen: revista de trabajo social y ciencias sociales, 89(6), 1-10.
Schein, E. H. (2010). Organizational culture and leadership (Vol. 2). John Wiley \& Sons. http://dspace.vnbrims. org:13000/jspui/bitstream/123456789/2373/1/ORGANIZATIONAL\%20CULTURE\%20Organizational\%20Culture\%20 and\%20Leadership\%2C\%203rd\%20Edition.pdf

Szmulewicz, P., Gutiérrez, C., \& Winkler, K. (2012). Asociatividad y agroturismo: evaluación de las habilidades asociativas en redes de Agroturismo del sur de Chile. Estudios y perspectivas en turismo, 21(4), 1013-1034.

https://www.redalyc.org/articulo.oa?id=180724056012

Villano Ludeña, R. B., \& Villegas Huamani, M. M. (2019). La capacidad asociativa y su relación con el potencial exportador de los pequeños productores de papa nativa en Centro Poblado de Taramba, Andahuaylas, Apurímac-2019. Lima. https://repositorio.utp.edu.pe/handle/20.500.12867/2576

Yelissa, C. A. A. (2020). Centro de investigación y desarrollo agropecuario en Huancavelica.

http://repositorio.unfv.edu.pe/handle/UNFV/4507 